\title{
Persistent Effects of Early Childhood Education on High-Risk Children and Their Mothers
}

\author{
Craig T. Ramey \\ University of Alabama at Birmingham \\ Frances A. Campbell, Margaret Burchinal, \\ Martie L. Skinner, and David M. Gardner \\ University of North Carolina at Chapel Hill \\ Sharon L. Ramey \\ University of Alabama at Birmingham
}

\begin{abstract}
Child and mother outcomes are reported for the Abecedarian Project, an early childhood education, pediatric healthcare, and family support program for high-risk children and their mothers. Three randomized intervention conditions for at-risk participants were compared to a control condition. Randomized control group participants received family support social services, low-cost or free pediatric care, and child nutritional supplements but no additional educational program beyond what the parents and the local school system provided. The local community was generally affluent and well educated; disadvantaged families represented a small minority whose welfare was a high social and educational priority.

The educational intervention conditions were (a) preschool education for the first 5 years of life plus a supplementary kindergarten through 2nd grade Educational Support Program (Preschool plus K-2 Support), (b) preschool education (Preschool Only), and (c) $K-2$ Educational Support Program ( $K-2$ Only). Child outcomes were assessed with respect to cognitive development, academic achievement, grade retention, and special education placements. For mothers, the effect of having educational childcare during the preschool period was examined with respect to maternal educational gains and employment. Positive and systematic cognitive and academic achievement differences were found for children in the preschool treatment conditions, particularly when that condition was combined with the $K-2$ Educational Support Program. High-quality, consistently available preschool education was also associated with greater maternal educational advancement and higher levels of employment particularly for teenage mothers. These findings have direct relevance for education and welfare policies.
\end{abstract}

Intergenerational poverty is pernicious. Impairments in cognitive development, school performance, and social competence are all associated with grow-

This research was supported by grants from the National Institutes of Child Health and Human Development, the U.S. Department of Education, the Administration on Children, Youth, and Families, and the Carnegie Corporation.

We gratefully acknowledge the Investigators and support staff who participated in this study over the years, particularly noting the contribution of the study's Family Coordinator, Carrie Davis Bynum, who has been instrumental in maintaining the sample for this longitudinal research. Appreciation is also extended to the children and families who contributed so much of their time to the study over the years. Without them, it could not have been done.

Requests for reprints should be sent to Craig T. Ramey, Civitan International Research Center, University of Alabama at Birmingham, 1719 Sixth Avenue South, Room 137, Birmingham, AL 35294-0021. ing up poor (Duncan \& Brooks-Gunn, 1997; Duncan, Brooks-Gunn, \& Klebanov, 1994; Huston, 1992; McLloyd, 1998; Ramey, MacPhee, \& Yeates, 1982). Currently, approximately $23 \%$ of children spend some or all of their childhood in poverty (Hernandez, 1997, p. 18).

Over the past 4 decades, educators, psychologists, social workers, and physicians have designed multidisciplinary intervention programs to benefit children from high-risk families. These programs can be conceptualized as applied developmental science probes into factors associated with the malleability of developmental processes and outcomes (Ramey \& Finkelstein, 1981; Ramey et al., 1982; Ramey \& Ramey, 1998). A number of scientifically rigorous early childhood programs in which participants were randomly assigned to treatment and control groups 
have reported initially positive effects on the cognitive development of poor children (e.g., Bryant \& Maxwell, 1997; and Ramey \& Ramey, 1998; for reviews). However, only a few investigators of true experiments have conducted systematic, long-term, follow-ups of their samples into adolescence or beyond (e.g., Campbell \& Ramey, 1995; Gray, Ramsey, \& Klaus, 1982; Lazar, Darlington, Murray, Royce, \& Snipper, 1982; Schweinhart, Barnes, Weikart, Barnett, \& Epstein, 1993). Such long-term follow-up is important because it conditions practical expectations for the developmental outcomes associated with various early intervention procedures and thus is directly relevant to educational, welfare, and health policies.

It is the purpose of this article to report practical, long-term effects of the Abecedarian Project. The Abecedarian Project was a two-phase, comparative, early childhood education, pediatric healthcare, and family support program that began in early infancy. Three educational treatment conditions have been compared to an educational control condition. Child participants have now been followed systematically until 15 years of age.

\section{Method}

\section{Recruitment}

The Abecedarian Project was initially conceptualized as a randomized controlled trial of the efficacy of early intervention for children born to low-income, multirisk families. Local prenatal clinics and the department of social services were screened for eligible participants using the 13-factor Risk Index in Table 1. Families who expressed interest (99\%) were then visited by study personnel to conduct a formal assessment of the family's eligibility for inclusion in the project. The condition of random assignment to early childhood treatment or comparison groups was explained during the enrollment process. Ninety-three percent of eligible families chose to participate. Entry characteristics of the preschool treatment and control participants are presented in Table 2.

\section{Participants}

Four cohorts of infants, born between 1972 and 1977, were enrolled in the study. Newborns had to appear healthy and free from biological conditions associated with developmental disabilities. The enrolled sample included $111^{1}$ children, 57 randomly assigned to the preschool treatment group and 54 to the preschool control group.

The families were predominantly African American (98\%) although ethnicity was not a selection crite-

\footnotetext{
${ }^{1}$ Two families had two children each enrolled in the project.
}

Table 1. High-Risk Index

\begin{tabular}{|c|c|}
\hline Factor & Weight \\
\hline \multicolumn{2}{|l|}{ Mother's Educational Level (last grade completed) } \\
\hline 6 & 8 \\
\hline 7 & 7 \\
\hline 8 & 6 \\
\hline 9 & 3 \\
\hline 10 & 2 \\
\hline 11 & 1 \\
\hline 12 & 0 \\
\hline \multicolumn{2}{|l|}{ Father's Educational Level (last grade completed) } \\
\hline 6 & 8 \\
\hline 7 & 7 \\
\hline 8 & 6 \\
\hline 9 & 3 \\
\hline 10 & 2 \\
\hline 11 & 1 \\
\hline 12 & 0 \\
\hline \multicolumn{2}{|l|}{ Family Income (\$ per year) } \\
\hline 1,000 & 8 \\
\hline $1,001-2,000$ & 7 \\
\hline $2,001-3,000$ & 6 \\
\hline $3,001-4,000$ & 5 \\
\hline $4,001-5,000$ & 4 \\
\hline $5,001-6,000$ & 0 \\
\hline Father absent for reasons other than health or death & 3 \\
\hline Absence of maternal relatives in local area & 3 \\
\hline $\begin{array}{l}\text { Siblings of school age one or more grades behind } \\
\text { age-appropriate level or with equivalently low } \\
\text { scores on school-administered achievement tests }\end{array}$ & 3 \\
\hline $\begin{array}{l}\text { Payments received from welfare agencies within past } \\
3 \text { years }\end{array}$ & 3 \\
\hline $\begin{array}{l}\text { Record of father's work indicates unstable or } \\
\text { unskilled and semiskilled labor }\end{array}$ & 3 \\
\hline $\begin{array}{l}\text { Records of mother's or father's IQ indicate scores of } \\
90 \text { or below }\end{array}$ & 3 \\
\hline $\begin{array}{l}\text { Records of sibling's IQ indicates scores of } 90 \text { or } \\
\text { below }\end{array}$ & 3 \\
\hline $\begin{array}{l}\text { Relevant social agencies in the community indicate } \\
\text { the family is in need of assistance }\end{array}$ & 3 \\
\hline $\begin{array}{l}\text { One or more members of the family has sought } \\
\text { counseling or professional help in the past } 3 \text { years }\end{array}$ & 1 \\
\hline $\begin{array}{l}\text { Special circumstances not included in any of the above } \\
\text { that are likely contributors to cultural or social } \\
\text { disadvantage }\end{array}$ & 1 \\
\hline
\end{tabular}

Note: Criterion for inclusion in high-risk sample was a score of more than 11.

rion. At birth, $76 \%$ of the children lived in single parent or multigenerational households. Mothers' ages ranged from 13 to 44 years, with an average age of slightly less than 20 years. Mean maternal education when the focal child was born was approximately 10th grade in both groups. Average maternal IQ as assessed by clinical examination was approximately 85 .

Of the 57 children (from 55 families) originally assigned to the preschool treatment group, 48 remained in the study through the 8-year experimental period (84\% retention); of the 54 preschool control group children, 42 remained (78\% retention). Analysis of the key demographic factors for the 19 families lost to attrition showed no significant differences from those re- 
RAMEY ET AL.

Table 2. Entry Level Demographic Data for Preschool-Treated and Control Families

\begin{tabular}{|c|c|c|c|c|c|c|}
\hline \multirow[b]{3}{*}{ Variables } & \multicolumn{6}{|c|}{ Group } \\
\hline & \multicolumn{2}{|c|}{ Experimental $^{\mathrm{a}}$} & \multicolumn{2}{|c|}{ Control $^{\mathrm{b}}$} & \multicolumn{2}{|c|}{ Total $^{\mathrm{c}}$} \\
\hline & $M$ & $S D$ & $M$ & $S D$ & $M$ & $S D$ \\
\hline Mean Maternal Age (years) & 19.56 & 3.88 & 20.28 & 5.77 & 19.92 & 4.90 \\
\hline Mean Maternal Education (years) & 10.45 & 1.75 & 9.98 & 1.91 & 10.22 & 1.84 \\
\hline Mean Maternal Full Scale IQ & 85.49 & 12.43 & 84.18 & 10.78 & 84.84 & 11.61 \\
\hline Percentage Intact Family & 23 & & 26 & & 24 & \\
\hline Percentage African American & 96 & & 100 & & 98 & \\
\hline
\end{tabular}

${ }^{\mathrm{a}} N=55 \cdot{ }^{\mathrm{b}} N=54 \cdot{ }^{\mathrm{c}} N=109$.

tained, with the exception that $71 \%$ of the lost participants were girls.

\section{Experimental Phase I: Abecedarian Preschool Program}

The Abecedarian preschool treatment and control conditions are summarized in Table 3. Study particulars have been reported in detail in previous publications (Ramey, Bryant, Campbell, Sparling, \& Wasik, 1988; Ramey, Campbell, \& Blair, 1998; Ramey \& Haskins, 1981; Ramey et al., 1982; Ramey, McGinness, Cross, Collier, \& Barrie-Blackley, 1981; Ramey, Sparling, \& Wasik, 1981). Therefore, the treatment and control conditions will be summarized only briefly here.

\section{Conceptual Framework}

In general, the Abecedarian preschool program was a comprehensive education, healthcare and family support program that provided an individualized approach to at-risk children and their families, drawing as needed on a pool of available services. The preschool intervention program's conceptual framework derived from developmental systems theory (Bertalanffy, 1975), which articulates the role of a stimulus-rich, positive, responsive social environment in facilitating instrumental and conceptual learning (Ramey \& Finkelstein, 1981). Pragmatic features of conversational language were given a strong emphasis (Ramey, McGinness, et al., 1981; Vygotsky, 1978). Ramey and Ramey (1998) summarized these orientations into a general developmental conceptual framework called Biosocial Developmental Contextualism that emphasizes the quality and quantity of adult-child transactions as one major pathway undergirding early brain and behavioral development. Biosocial Developmental Contextualism also explicitly acknowledges the importance of developmental genetics and neurobiology, health conditions, and sociological norms and practices as major influences on individual development. For these and other reasons, health care, good nutrition, and family support services were an integral part of the program. Services were provided based on continuous assessments of family needs and the daily status and behavior of children.

\section{Program Goal}

The primary goal of the preschool phase (Phase I) was to enhance school readiness and, thus, to establish a better base for a successful transition into elementary school. It is important to note that the Abecedarian Project was located in a generally affluent college town where the vast majority of families were well educated. Thus, there were relatively few families in the local population who would be considered socioeconomically at risk. Those who did fit this category tended to be of African American descent. The community leaders had a generally progressive stance toward disadvantaged families and therefore provided funds for many public and private services for those in need. In the year in which the project began, for example, there were 33 separate agencies in the town devoted, in whole or in part, to meeting the needs of poor and multirisk families. Those services are presumed to have improved the performance of the control group children over what would have occurred in a poorer, less resourceful community. Moreover, the Abecedarian Project provided additional services to both treated and control group participants, including referrals of control children for follow-up treatment in cases where study assessments indicated poor cognitive performance of clinical significance. It is thus reasonable to view the research design as a conservative test of the power of educationally oriented, systematic, early intervention with an emphasis on early childhood education to affect the life course of children from intergenerationally poor and multirisk families.

\section{Preschool Intervention Effects}

To place the Abecedarian K-2 Educational Support Program and the long-term follow-up in life-course context, we briefly summarize findings from the preschool period into six key points. For each point, pertinent references containing additional details are noted. 
Table 3. Summary of Abecedarian Preschool Treatment and Control Conditions

\begin{tabular}{ll}
\hline Preschool Treatment $^{\mathrm{a}}$ & \multicolumn{1}{c}{ Control Treatment $^{\mathrm{b}}$} \\
\hline Nutritional Supplements & Nutritional Supplements \\
Family Support Social Services & Family Support Social Services \\
Pediatric Care and Referral & Pediatric Care and Referral \\
Early Childhood Education & \\
6 weeks to 5 years of age & \\
Good teacher-child ratios and a year-round program & \\
$\quad$ that met or exceeded NAEYC Standards & \\
Developmentally appropriate practices & \\
Hours of operation: 7:30 a.m. to 5:30 p.m. & \\
$\quad$ Partners for Learning curriculum plus other & \\
$\quad$ documented approaches & \\
Preservice and inservice training & \\
Individualized learning experiences in natural & \\
$\quad$ preschool atmosphere & \\
Emphasis on language, cognition, social, emotional, & \\
$\quad$ and physical development & \\
Promotion and support for parent involvement & \\
Daily transportation & \\
\hline
\end{tabular}

Note $:$ NAEYC $=$ National Association for the Education of Young Children.

${ }^{\mathrm{a}} N=57 .{ }^{\mathrm{b}} N=54$.

1. Preschool intervention reduced the incidence of delayed cognitive development during the preschool years.

Effect Sizes. Developmental delay, on average, was first detected in the control group in the 2nd year of life and persisted throughout the preschool years (Ramey \& Campbell, 1984). Figure 1 (created from data reported by Ramey [1992] and Ramey \& Campbell [1984]) depicts the average $z$ scores from 3 to 54 months after amalgamating the data of treated and control participants at each age, standardizing the combined distribution and then calculating the mean $z$ scores for the treatment and control groups separately.

The graph depicts data from the Bayley Mental Development Index, the Stanford-Binet IQ and the McCarthy Scales of General Cognitive Development at appropriate age points in months. The number at each $z$ score is the treatment or control group mean IQ score or equivalent. ( $M=100, S D=15$ in the standardization samples of these tests). Below each age point on the $X$ axis is the effect size estimates based on IQ scores using the following formula:

$$
\frac{M \text { treatment group }-M \text { control group }}{S D \text { of control group }}
$$

Effect sizes greater than .25 are generally considered by educators to have practical significance (Cohen, 1977). Our calculations reveal that the effect size differences at 3 months were nonexistent. Over the first 18 months of age the differences became larger and consistently favored the performance of the preschool treated group over the control group. The average effect size of preschool treatment between 18 months and $4 \frac{1}{2}$ years was 1.08 , a remarkably large average effect size in the early intervention literature.

Practical Significance. To learn the extent to which the High-Risk Index successfully identified children at risk for developmental retardation during the preschool period, Ramey and Campbell (1984) reported the percentages of children who obtained a Stanford-Binet IQ of 85 or less at various occasions during the preschool years. For example, at 48 months approximately $40 \%$ of control group children scored in this range compared to less than $5 \%$ of the preschool intervention group.

2. The most vulnerable children benefitted the most from the preschool program. We estimated the effects of the preschool treatment on intellectual development from 6 through 54 months of age (Martin, Ramey, \& Ramey, 1990). The IQs of preschool treatment group children ranged from 8 to 20 points higher than those of control children when maternal mental retardation and home environment, both important factors in the occurrence of developmental delay, were statistically accounted for via multiple-regression analyses. The children who benefitted the most had mothers with IQs below 70 .

3. Some preschool control group children benefitted from other preschool programs. Burchinal, Lee, and Ramey (1989) reported analyses that demonstrated the positive association between attendance at other preschool programs and cognitive performance during the prekindergarten years.

4. Preschool intervention increased children's cognitive resilience to nonoptimal biological and behavioral conditions. The Abecedarian Preschool Treatment significantly ameliorated the effects of some biological and behavioral risk factors including low Apgar scores 
RAMEY ET AL.

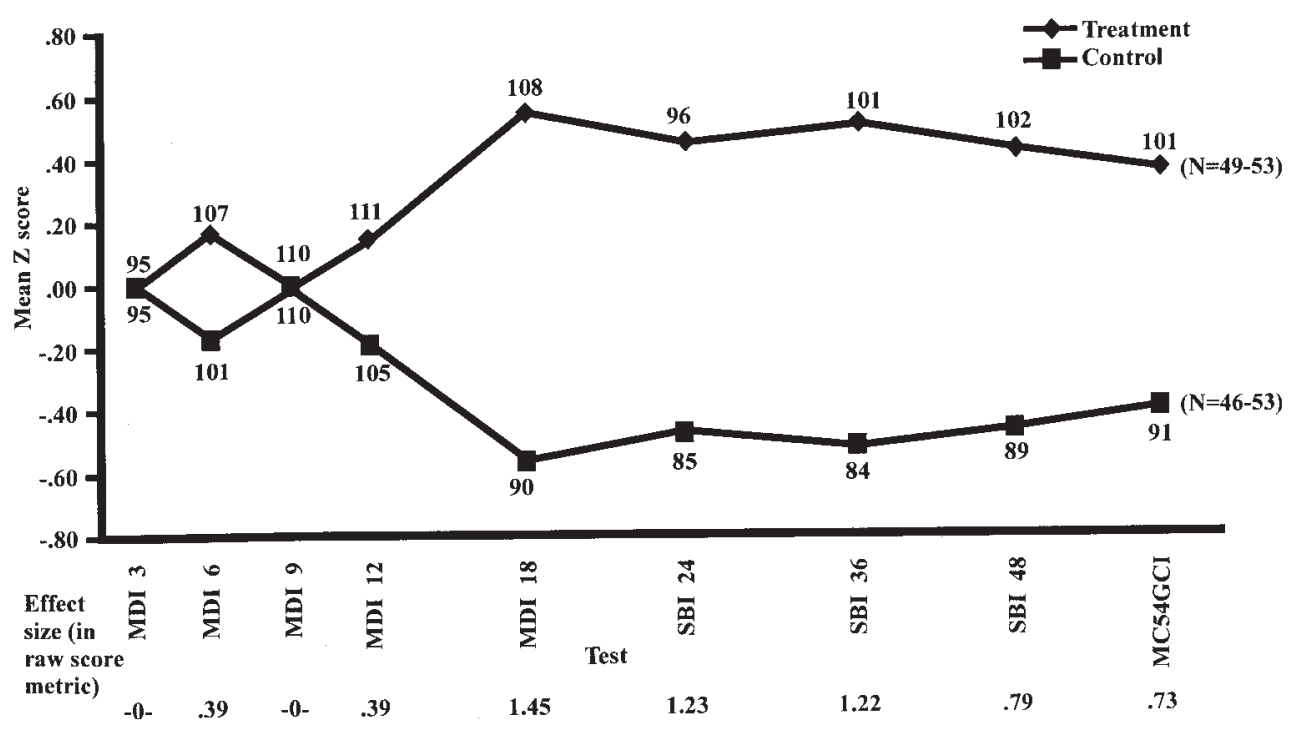

Figure 1. Mean $Z$ scores and mean standardized scores for high-risk preschool treatment and control children in the Abecedarian Project at nine preschool measurement occasions.

(Brietmayer \& Ramey, 1986), difficult temperament (Ramey et al., 1982), and fetal undernourishment (Zeskind \& Ramey, 1978, 1981). The primary mechanism for this increased resilience was through improving children's cognitive development by enhancing their responsiveness to their early social environments (Burchinal, Campbell, Bryant, Wasik, \& Ramey, 1997).

5. The Abecedarian Preschool Program did not harm the mother-child attachment process or mother-child interactions. Home observations using Caldwell and Bradley's Home Observation for Measurement of the Environment instrument (Caldwell \& Bradley, 1984) revealed no measurable negative effect on the socioemotional climate of the home associated with the preschool treatment program (Ramey, Mills, Campbell, \& O'Brien, 1975). This finding is buttressed by similar conclusions from the recent report from the National Institute for Child Health and $\mathrm{Hu}-$ man Development (NICHD) longitudinal study of day care (NICHD Early Child Care Research Network, 1997). Direct observations of mother-child interactions under laboratory conditions revealed that mothers and children tended toward more involvement as a dyad if the child was enrolled in the preschool (Farran \& Ramey, 1980). It is noteworthy that this finding has recently been confirmed with a much larger sample in the Infant Health and Development Program, an educational intervention for low-birth-weight children whose treatment represented a slight modification of the Abecedarian Preschool Program (Spiker, Ferguson, \& Brooks-Gunn, 1993).

6. Teen mothers of children receiving the center-based preschool program had an increased likelihood of completing high school and obtaining postsecondary training. By the time their children entered kindergarten, $46 \%$ of teen mothers in the pre- school treatment group had graduated from high school and obtained postsecondary training compared to only $13 \%$ in the control group (Campbell, Breitmayer, \& Ramey, 1986).

\section{Phase II: Abecedarian K-2 Educational Support Program}

\section{Research Design}

Given the positive preschool effects on children and their mothers, at kindergarten entry we were faced with a dilemma. Should we simply follow these children's progress in school to see how they fared or should we provide an educational support program to aid their transitions into school? Because there were no directly relevant data from previous randomized controlled trials to guide us, we decided to do both, and to do so within the two-stage randomized design presented in Figure 2.

We made this decision although we realized that subdividing a relatively small group of children and families had the disadvantage of reducing the statistical power to detect group differences. On balance, however, we decided that the potential scientific benefits outweighed the risks associated with reduced statistical power. The new design necessitated a revision of our basic statistical approach (a two-group comparison). We now proposed the additional hypothesis that cognitive and academic achievement benefits should be proportional to the duration of the intervention as tested by linear trend analyses of variances (for continuously distributed outcome variables), across the four groups. We then complemented that analysis with a preschool versus no preschool contrast.

At school entry, each cohort of children was rank ordered by 48-month Binet IQs from highest to lowest 


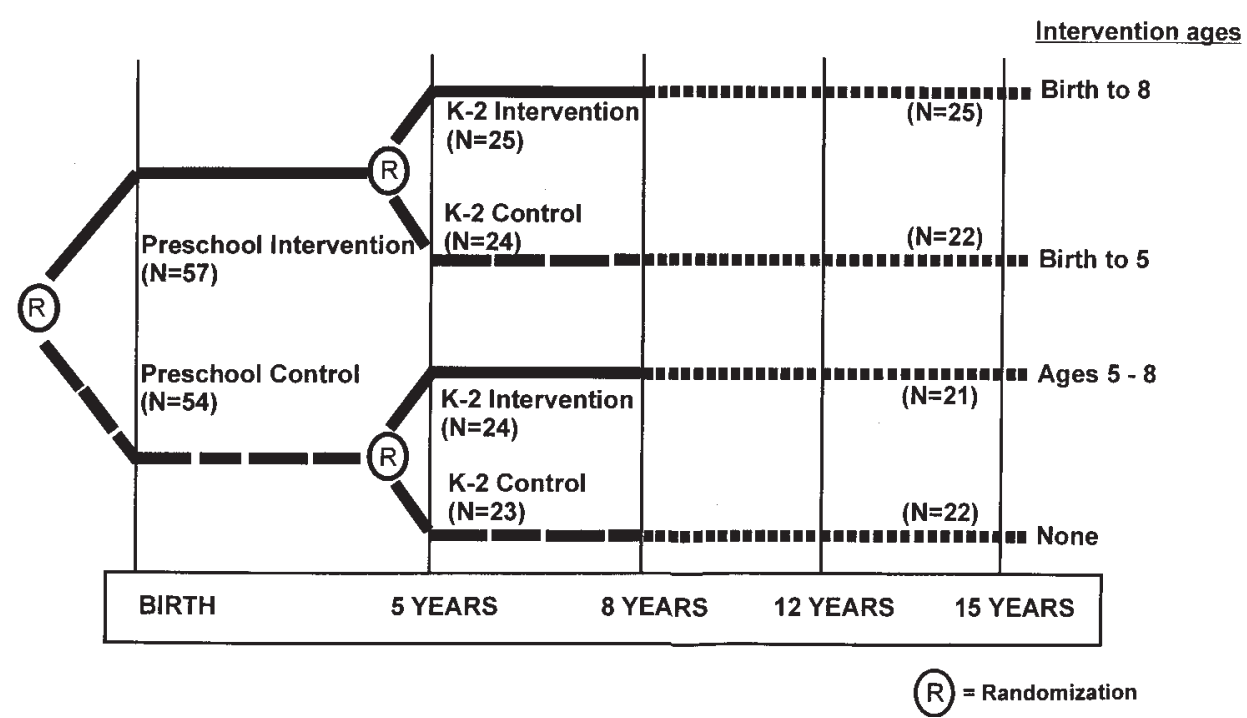

Figure 2. Design of Abecedarian Project.

within both the preschool treatment and control groups. One member of each consecutive pair within each group was then assigned randomly to the Abecedarian K-2 Educational Support Program.

This design provided the opportunity to examine and compare the long-term effects of (a) early and continuing intervention, (b) early intervention only, and (c) late intervention only, relative to performance of participants in a continuous control group.

We turn now to a brief description of the K-2 Educational Support Program.

\section{Abecedarian K-2 Educational Support Program: Conceptual Framework}

The K-2 Program was consistent with the hypothesis that supplementary intervention programs potentially can influence children via modifications in their social environments and learning experiences. It was based largely on the view that parent involvement in schoolwork is an important factor in public school success. The support program was therefore designed to influence the child's home learning support, to individualize school experiences during the academic year in a developmentally appropriate fashion, and to provide additional learning support over the summer-a period during which high-risk children typically lose ground academically (Entwistle \& Alexander, 1998). Thus, school-age treated children were offered educational support both in school and at home for the first 3 years they attended public school. Classroom teachers were given continuing consultation and technical assistance to ensure that children's school experiences were developmentally appropriate and parents were shown how to enhance schoolwork by engaging in specific supplemental educational activities at home.

These educational support services were provided by master teachers with extensive, successful back- grounds in primary education, and successful experience in working with at-risk children and families. Known as Home-School Resource Teachers (HSTs), these professionals had graduate degrees in education.

We hypothesized that regular visits by a professional educator who knew the challenges and joys of classroom teaching and had specific knowledge about the child's classroom activities and performance, would help high-risk parents feel more comfortable in helping their children successfully negotiate school routines and meet academic demands. These parents, many of whom had had great difficulty in school themselves, would benefit from an HST who could answer their questions, discuss their concerns, and demonstrate specific learning materials and procedures. At times, the HSTs encouraged schools to refer children for available special services, and helped parents to be actively involved in the referral process and educational therapies provided.

The activities by the HSTs were conceptualized as supplements to the school's regular educational program. No part of the K-2 program was intended to preclude the child's regular school participation or to supplant any services the schools had to offer. It should be noted that the public schools in the university town where the study was conducted were generally well regarded and consistently performed near or at the top of public schools throughout the state on measures of student performance. Further, although at-risk students made up only a very small portion of the student body, a high level of resources was devoted to their education and general welfare. Analogous to the stringency of comparing preschool program outcomes for children and parents in a resource-rich community, the many school-based programs for children at risk makes the comparison of school-age treatment and control group differences a stringent one in relation to what might have been obtained in less resourceful systems. The 
availability of many learning supports (reading groups, pull-out special education programs, self-contained classes) probably undergirded and raised the school performance of the control group children relative to what would have been obtained in less resourceful school districts.

Typically, an HST worked each year with 12 children, their families, and their classroom teachers. She became an advocate for the family within the school and community systems and for the school within the family.

\section{Learning Activities}

Individualized learning activities based on the objectives established with the classroom teacher were a major component of the $\mathrm{K}-2$ program. A task-analysis approach defined the component skills necessary to achieve each objective. The sequencing of tasks into manageable steps, characteristic of the task-analysis approach, was used. The activities were calibrated to be challenging but within the child's range of success.

In a typical year, approximately 60 different learning activities were designed for each child. A log of these activities was maintained by the HST to document the curriculum. The primary emphasis for these activities was on basic skills in reading and mathematics. Many were original games created by HSTs. In addition, ready-made activities to give practice in handwriting, phonics, and math concepts and facts were also used. The caregiver was asked to use the activities with the child on a regular basis. On subsequent visits, parents always were asked for feedback on the materials, including how much time they had spent doing them during the previous 2 weeks. Parents were asked to document their use of these activities on a special calendar provided by the HST.

The learning materials were generally popular with parents; most reported high levels of success and satisfaction in using them. On average, parents reported that they worked with their child about 15 minutes a day. Parents especially liked the specificity of the activities because, as one parent said, "they took the guess work out of what to do."

\section{Other Family Services}

Family life and adult issues were also discussed with HSTs at the parents' initiation. Many mothers said that they derived social support from their home visitors, and came to reveal to them personal concerns and problems and to seek advice or help. Parents were referred as necessary to community agencies for social services, housing, medical care, adult education, or employment.

\section{Summer Program}

In addition to the Abecedarian K-2 school-year program, children were provided with summer camp experiences. While they offered many traditional camp activities, such as arts and crafts, music, games, and sports, these camps also had a "hidden curriculum" in that they featured academic skills in a playful context. Camps were 8 weeks in duration, were based in an elementary school, and made extensive use of community parks, pools, and recreation centers. The camps were staffed by the HSTs and supplemented by paid and volunteer students and adults. Table 4 contains a brief summary of the Abecedarian K-2 Transition Program.

Overall, teachers were positive about the $\mathrm{K}-2$ program and the parents participated enthusiastically and frequently in the home activities. At the project's end, all parents reported that they had found it a very positive experience and would have liked to continue to participate if the program had lasted longer.

\section{Long-Term Results: Academic Achievement, Intellectual Outcomes, and School Progress}

\section{Treatment Endpoint, Age 8}

Academic outcomes during the primary grades represent a direct and practical test of the efficacy of the K-2 Educational Support Program as well as an initial test of the persistence of the preschool effects in the case of no additional $\mathrm{K}-2$ program. Achievement in reading and mathematics was considered most important because these two basic subjects are crucial to success in the early elementary grades and they had been the primary focus of the K-2 Educational Support Program. Moreover, they are the skills to which teachers, school administrators, and the public pay particular attention. In this article we have presented age-referenced standard scores $(M=100, S D=15)$ on reading and math derived from the Woodcock-Johnson Psychoeducational Battery (Woodcock \& Johnson, 1977) individually administered to children at school by project personnel.

Table 4. Summary of Abecedarian K-2 Educational Support Program

Individualized focus on academically related activities in school and at home

Emphasis on reading, and mathematics, and writing

Master Home/School Resource Teachers with 12 children and families per year

Development of an individualized and documented supplemental curriculum for each child

Explicit attention and action relevant to family circumstances, as needed

Summer camps with academically relevant experiences 
We also have reported group administered achievement tests given by the school staff to elementary school children. The Woodcock-Johnson test results are consistent with those from the school administered tests, as reported by Horacek, Ramey, Campbell, Hoffmann, and Fletcher (1987). As noted before, we hypothesized a linear trend with academic performance increasing as a positive function of the duration of intervention. The age 8 standard score results for reading and mathematics performance are presented in Figure 3 . They conform perfectly to the expected pattern for both reading and math, but more dramatically for reading than for math.

Effect sizes for the three treatment conditions at age 8 were calculated relative to the mean and standard deviation for participants in the control condition. In Figure 3 the effect sizes for reading achievement at age 8 vary from .28 to 1.04 for the treatment conditions and are consistent with our hypothesis about duration of program, that is, the longer the program the larger the effect. The most effective treatment condition was the Pre-
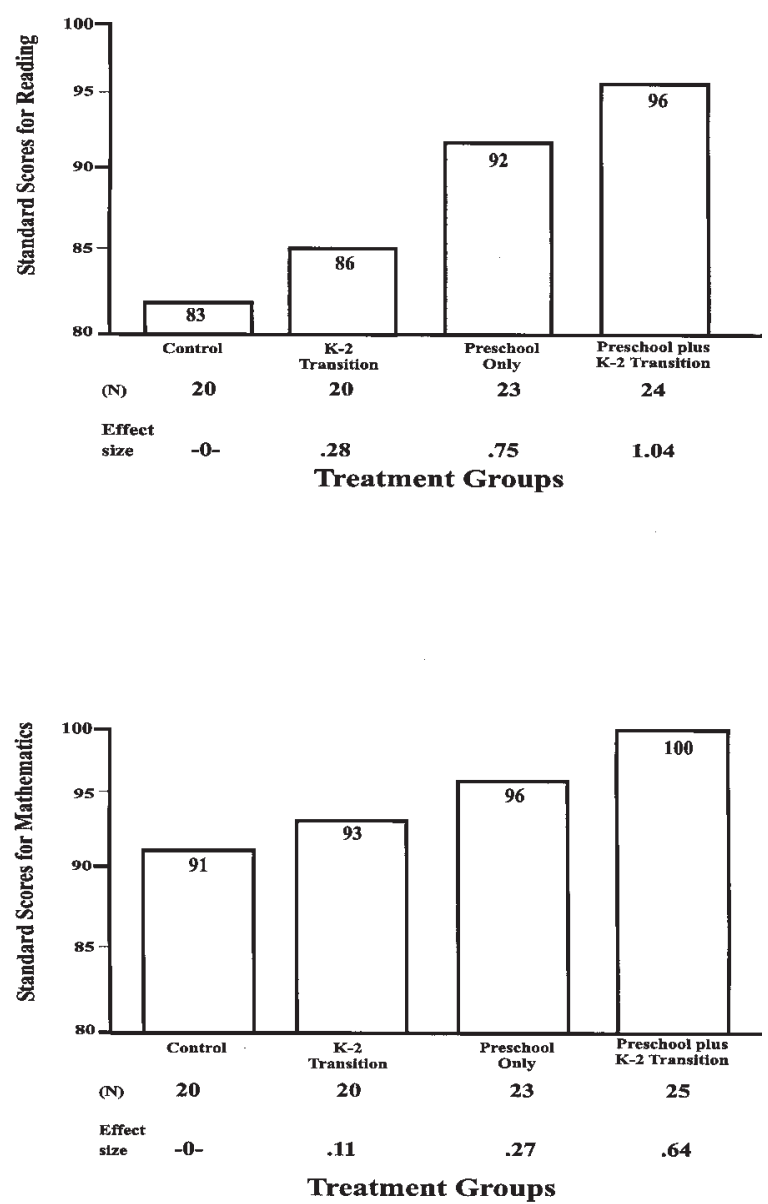

Figure 3. Abecedarian Project Woodcock--Johnson Age-referenced reading and mathematics standard scores at age 8. Effect sizes for the top graph are relative to the control condition and are calculated as $\frac{M_{\mathrm{T}}-M_{\mathrm{c}}}{\mathrm{C}_{\mathrm{c}}} \mathrm{T}=$ treatment condition; $\mathrm{C}=$ control condition. school Plus K-2 Program, followed by the Preschool Only, and then the K-2 Program Only, relative to controls. A similar pattern of findings was obtained for mathematics achievement with somewhat more modest effects (i.e., effect sizes ranging from .11 to .64). Overall, the K-2Educational Support Program, by itself, was marginally significant for reading $(E S=.28)$ but not practically significant for mathematics $(E S=.11)$.

\section{Academic Achievement at Age 12}

It was only possible to provide the Educational Support Program for the first 3 years in school. Thereafter, the Abecedarian Project conducted two follow-up studies. When the children were 12 years of age we repeated the earlier assessments of cognitive and academic achievements. Woodcock-Johnson results are presented in Figure 4. At age 12 the treatment effect sizes across the three groups range from .23 to .86 for reading and from .24 to .63 for math. For reading, the pattern is strikingly consistent with what was obtained at age 8 with the Preschool Plus K-2 Support condition producing the largest effects followed by the Preschool Only condition followed by the K-2 Program Only. For math the pattern was similar with the exception that the two preschool conditions were very similar.

\section{Academic Achievement at Age 15}

A subsequent follow-up was conducted 3 years later when child participants had completed 10 years in school and were turning 15 years old. This probe permitted us to assess progress in middle adolescence, just prior to the age when school attendance is no longer mandated in the local school district.

When the follow-up study was conducted at age 15 we again observed the same pattern of scores for reading and mathematics as was seen at age 12 (Figure 5). The effect sizes varied from .14 to .87 in proportion to duration of treatment for reading and from .09 to .65 for mathematics. Again, there was a strong effect both for the Preschool Plus K-2 Educational Support Program and for the Preschool Only condition. By this age, however, the K-2 Program, by itself, proved to be of no practical lasting benefit. Thus, there is clear evidence for a practical and persistent effect of intensive early intervention and especially so for reading when it was supplemented by the K-2 Transition Program.

\section{Long-Term Intellectual Outcomes}

Figure 6 presents the mean $z$ scores on age-appropriate Wechsler Scales of Intelligence from 

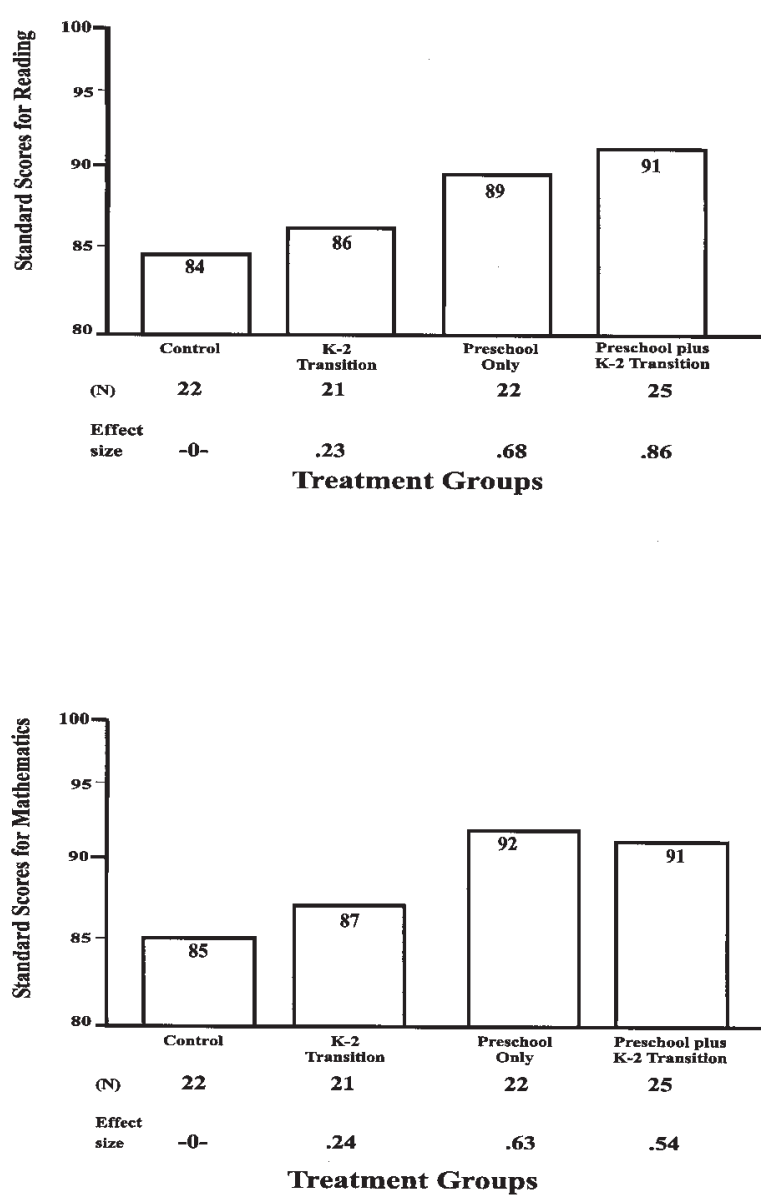

Figure 4. Abecedarian Project Woodcock-Johnson Age-referenced reading and mathematics standard scores at age 12. Effect sizes for the top graph are relative to the control condition and are calculated as $M_{\mathrm{r}}-M_{\mathrm{c}}$. $\mathrm{T}=$ treatment condition; $\mathrm{C}=$ control condition.

age 5 to age 15 for each of the four groups. The right side of the figure also lists the mean age 15 standardized Wechsler Intelligence Scale for Children-Revised IQ scores. Repeated measures analyses of variances for the $z$ scores revealed a main effect for the preschool condition only. The $z$ score effect sizes for the preschool treatment groups average .39 and show no significant time trends over the 10-year period covered.

Following up the finding that children of very low IQ mothers benefitted most from early treatment, we examined the effect size of preschool treatment on child IQ at age 15. Among the 12 individuals for whom follow-up data were available ( 6 treatment and 6 controls) the effect of preschool treatment on child IQ continued to be substantial-10 IQ points (91 vs. 81 respectively) for an effect size of .76.

\section{Retention in Grade up to Age 15}

One important real-world measure of a student's scholastic progress is retention in grade. Independently of whether this is an effective remedial practice, it clearly indicates that the school faculty was dubious about the child's readiness for a more advanced curriculum. At age 15, information about grade retention was extracted from school records.

The findings here are quite striking. Only the preschool program had an effect on grade retention-reducing it from $55 \%$ overall to $30 \%$ overall. The $\mathrm{K}-2$ Program by itself had no measurable effect.

\section{Special Education Placement to Age 15}

Figure 7 shows the percentage of individuals in each treatment group who had never been assigned to special services over the 10 years they attended school. The figures indicate that students in the preschool control condition were more likely to be placed, but the expected linear trend showing fewer placements as years of treatment increased, is not seen. The special education data need to be interpreted, we think, in light of the role of the HSTs who were Special Educators and who
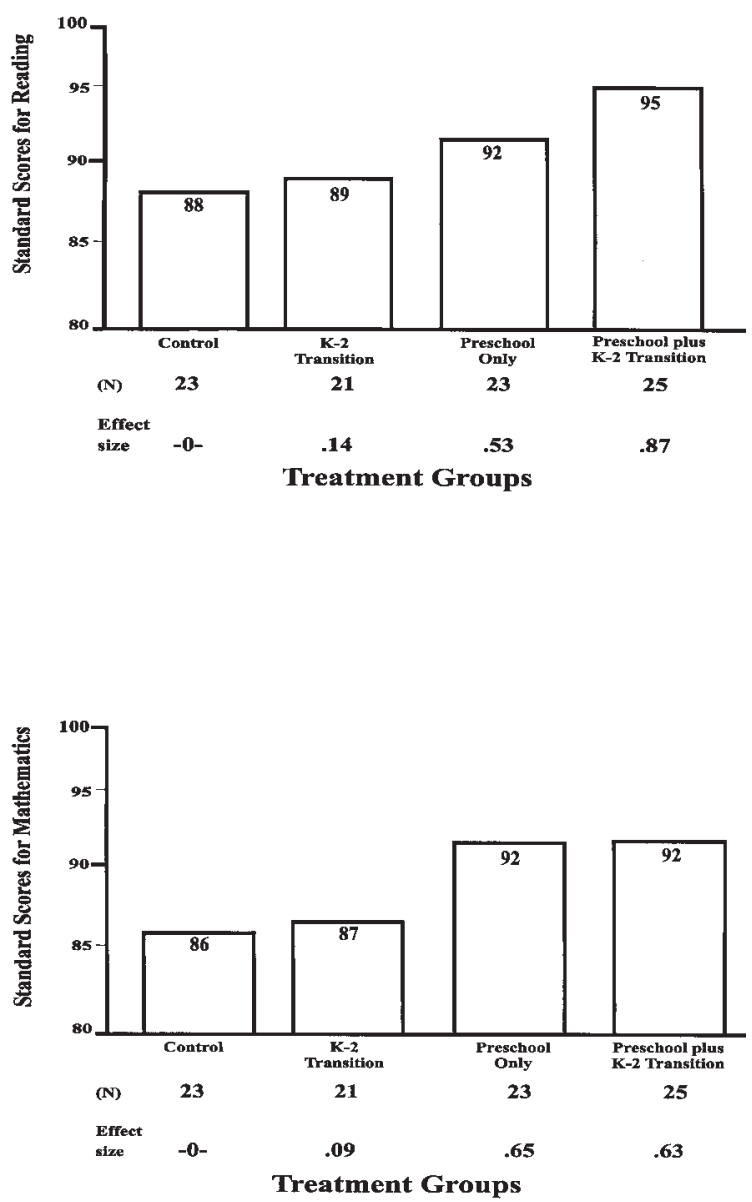

Figure 5. Abecedarian Project Woodcock-Johnson Age-referenced reading and mathematics standard scores at age 15. Effect sizes for the top graph are relative to the control condition and are calculated as $\underline{M_{\mathrm{T}}-M_{\mathrm{c}}} . \mathrm{T}=$ treatment condition; $\mathrm{C}=$ control condition. 


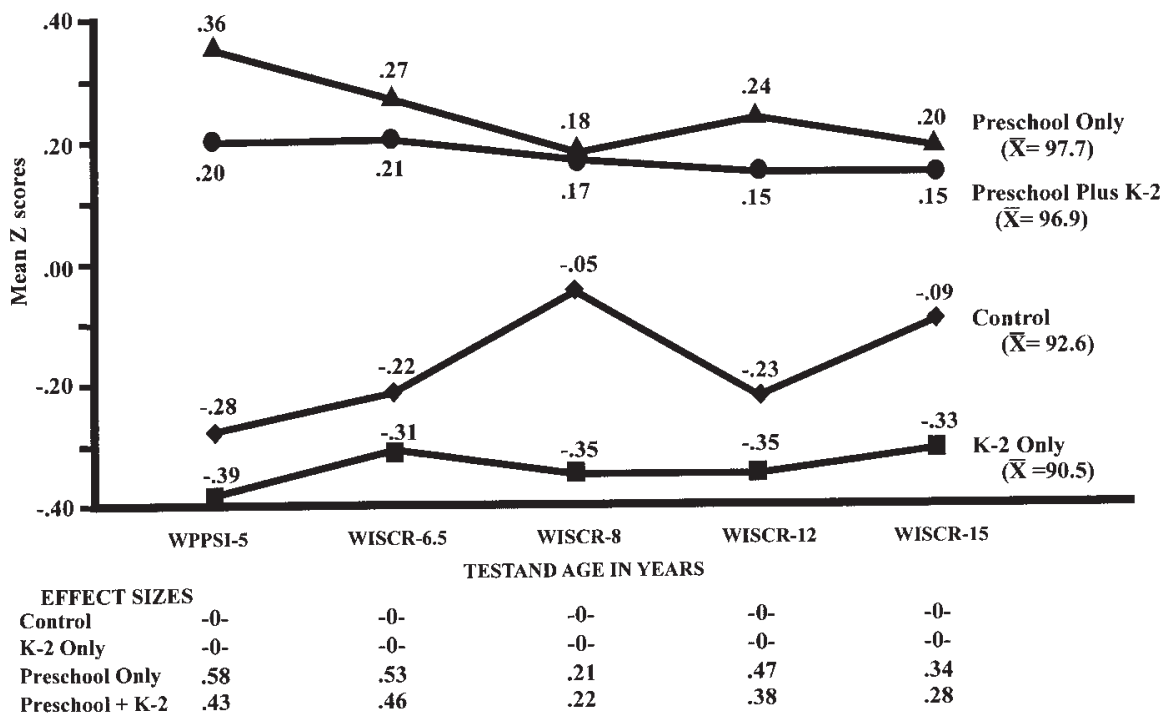

Figure 6. $Z$ scores and effect sizes in intellectual performance as a function of treatment condition in the Abecedarian Project.

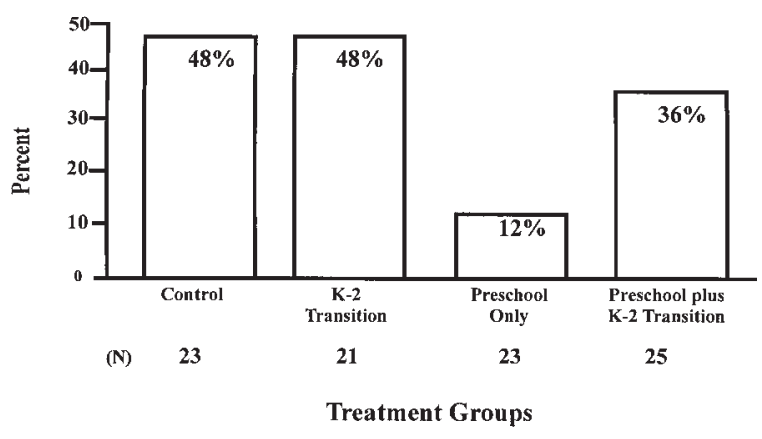

Figure 7. Abecedarian Project-Percentage of treatment group participants assigned to special services, grades K-9.

therefore sought out special education services whenever they were thought to be potentially useful. During the primary years, the increased developmental surveillance afforded by the $\mathrm{K}-2$ program may have inflated the rate above what would have occurred in the natural ecology. The most unbiased estimates of a preschool effect can probably be obtained in the Preschool Only versus control comparison. In that comparison $12 \%$ of the Preschool Only group was placed in special education versus $48 \%$ of the control group.

\section{Maternal Outcomes}

For parents, the most likely important aspect of family support afforded by the Abecedarian early childhood program was 5 years of free, full-time, educational childcare and accompanying services. Thus, a major question was the significance of this service in the lives of the mothers who received it. We examined the effects of preschool treatment on maternal educational change and employment. The biological mother was the custodian of record for all child participants at study entry. Subsequent examination of gains in maternal education was necessarily confined to those cases where data for the same individual were again available.
Figure 8 shows the percentage of all mothers in the preschool treatment and control groups who reported having attained education beyond high school at the time of their child's birth, and at three later points: after 4, 8 , and 15 years. The figure also contains this information for the subsample of mothers who were teens (aged 17 or younger) when the target child was born. The younger mothers whose children had preschool intervention were significantly more likely to have post high school educational attainment by the time their children were age 15 (80\%) than comparable control mothers (28\%).

Figure 9 shows the rates of employment for the entire sample and for the subsample of teen mothers within each full set, at age 15 . The mothers most likely to be employed were teen mothers in the preschool treatment group (92\%) and the least likely were teen mothers in the preschool control condition (66\%).

\section{Discussion}

The Abecedarian Project children showed positive cognitive effects of participating in an early intervention program. These preschool effects have now been replicated in Project CARE (Ramey, Bryant, Sparling, \& Waski, 1985; Wasik, Ramey, Bryant, \& Sparling, 1990) and the Infant Health and Development Program (1990; Ramey et al., 1992). In the Abecedarian Program, up to at least 10 years after intervention ended, children with preschool intervention significantly outscored those in the preschool control group on standardized measures of academic achievement and were less likely to be retained in grade or placed in special education. This was particularly true when the preschool intervention was followed up with the $\mathrm{K}-2$ Educational Support Program. This finding is currently being pursued in a separate experiment on a much larger scale in the Head-Start-Public School Transition Demonstration Project (Ramey \& Ramey, in press). 


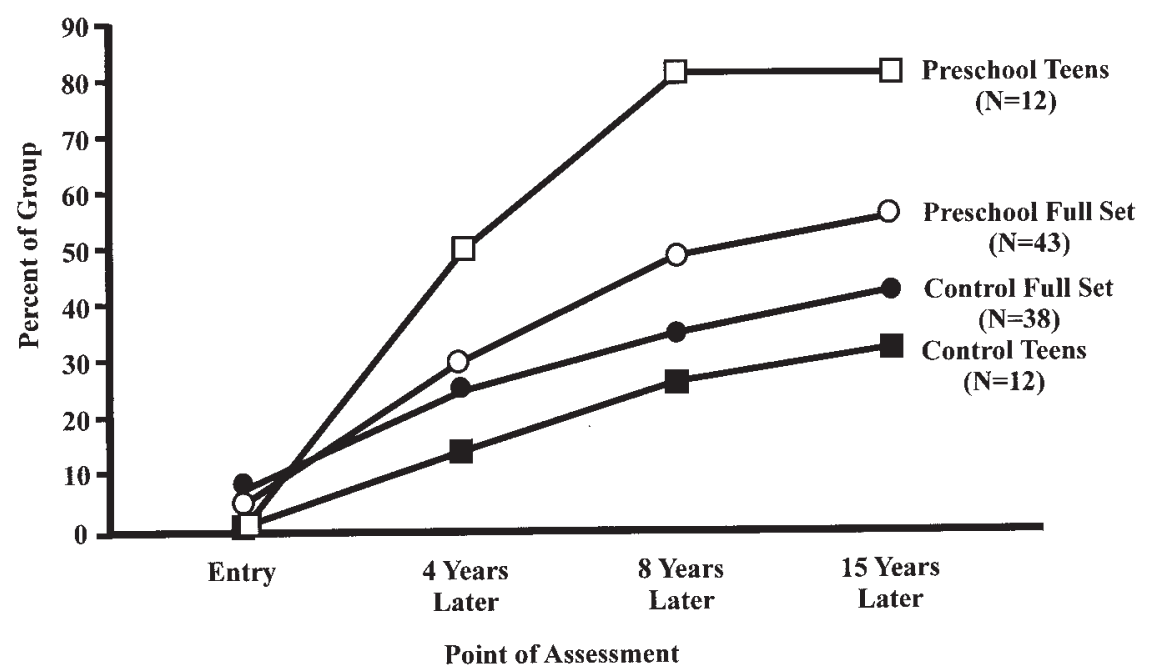

Figure 8. Percentage of total group and teen mother subgroup with post high school education at study entry and three subsequent points by preschool treatment group.

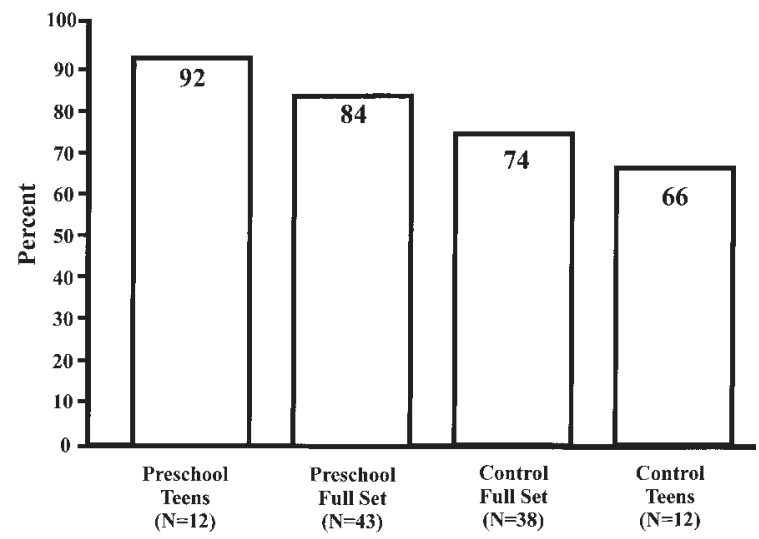

Figure 9. Percentage of full set of teen mothers employed when children were age 15.

Mothers whose children received high-quality, full-time childcare during the preschool years in the Abecedarian Project made gains in their own educational attainment and employment relative to mothers in the preschool control group. Educational gains were particularly striking for women who were teenagers when their child was born. These findings have clear relevance to current debates about welfare reform.

It remains to be seen whether the practically significant and persistent academic gains made by the high-risk children who experienced preschool treatment ultimately lead to better social adjustment and greater degrees of self-sufficiency in adulthood. These issues are being pursued in follow-up work that is currently in progress.

In this era of education, health, and welfare reform the Abecedarian findings are germane to the public policy discussions. Specifically, if high-quality childcare is available, many poor women will avail themselves of the opportunity to become better prepared education- ally. This effect is greatest for teen mothers who are having their first child. Such young women transform these educational gains into meaningful employment. This makes sense because providing childcare for a second or third child in a family does not change the mother's situation as much as providing that care for an only child or for all children. This, however, does not fully address the problem of unemployment of undereducated mothers. There must be good jobs for which poor women can train. In the Research Triangle area of North Carolina, during the conduct of this study, unemployment averaged less than 3\%. Most mothers found jobs eventually, but there was a disturbing trend for younger women, who had not had the benefit of the preschool childcare program, to have the highest rate of unemployment as their children got older.

Early childhood programs alone probably cannot fully meet the needs of young children as they progress through school. These children appeared to enter school ready to learn, and those with preschool treatment had an academic advantage still apparent after 10 years in school. Their advantages, however, were enhanced by a specific and intensive school-age program that aided their transition into public school and provided them with specialized support for early school learning. This finding is particularly important in recognition of the town in which the study was conducted, a moderate-sized college town located in the burgeoning Research Triangle. Throughout the time that the study has been conducted the economy in that area, which includes Raleigh, Durham, and Chapel Hill, has been one of the most rapidly expanding and robust in the country with very low rates of unemployment. The school system was strong and the proportion of disadvantaged children was below $10 \%$. A strong social ethic to help disadvantaged children and families was accompanied by strong in-school programs for disadvantaged children. Many 
high-quality family support programs, both public and private, operated in the local community. Thus, it is particularly noteworthy that, in addition to these services, the high-risk children nonetheless needed further educational assistance, as reflected by the higher rates of academic failure and special education placement in the educationally untreated Abecedarian control group. When such assistance was provided to the treated group in the form of a high-quality preschool, especially when an additional K-2 Educational Support Program was added, high-risk children performed near the national average in reading, even after 10 years in school. Positive effects were also seen in mathematics performance.

We are currently concentrating on two main questions in our continuing research program within the Abecedarian Project. First, to what extent do these academic advantages and disadvantages relate to early adulthood educational, social, and economic competence? And, second, what are the mediating and moderating factors linked to differential outcomes? It is our hope that this research program will help to show effective and practical ways to alter the life course of children and families who begin life in high-risk circumstances.

\section{References}

Bertalanffy, L. V. (1975). Perspectives on general system theory. New York: Braziller.

Breitmayer, B. J., \& Ramey, C. T. (1986). Biological nonoptimality and quality of postnatal environment as codeterminants of intellectual development. Child Development, 57, 1151-1165.

Bryant, D., \& Maxwell, K. (1997). The effectiveness of early intervention for disadvantaged children. In M. Guralnick (Ed.), The effectiveness of early intervention (pp. 23-46). Baltimore: Brookes.

Burchinal, M. R., Campbell, F. A., Bryant, D. M., Wasik, B. H., \& Ramey, C. T. (1997). Early intervention and mediating processes in cognitive performance of children of low-income African American families. Child Development, 68, 935-954.

Burchinal, M. R., Lee, M., \& Ramey, C. T. (1989). Type of day care and preschool intellectual development in disadvantaged children. Child Development, 60, 128-137.

Caldwell, B. \& Bradley, R. (1984). Home Observation for Measurement of the Environment. Little Rock, AR: University of Arkansas at Little Rock.

Campbell, F. A., Breitmayer, B. J., \& Ramey, C. T. (1986). Disadvantaged teenage mothers and their children: Consequences of educational day care. Family Relations, 35, 63-68.

Campbell, F. A., \& Ramey, C. T. (1995). Cognitive and school outcomes for high risk African American students at middle adolescence: Positive effects of early intervention. American Educational Research Journal, 32, 743-772.

Cohen, J. (1977). Statistical power analysis for the behavioral sciences (Rev. ed.). New York: Academic.

Duncan, G. J., \& Brooks-Gunn, J. (1997). Income effects across the life span: Integration and interpretation. In G. J. Duncan \& J. Brooks-Gunn (Eds.), Consequences of growing up poor (pp. 596-610). New York: Russell Sage Foundation

Duncan, G. J., Brooks-Gunn, J., \& Klebanov, P. K. (1994). Economic deprivation and early childhood development. Child Development, 65, 296-318.
Entwistle, D. R., \& Alexander, K. L. (1998). Facilitating the transition to first grade: The nature of transition and research on factors affecting it. The Elementary School Journal, 98, 351-364.

Farran, D. C., \& Ramey, C. T. (1980). Social class differences in dyadic involvement during infancy. Child Development, 51, 254-257.

Gray, S. W., Ramsey, B. K., \& Klaus, R. A. (1982). From 3 to 20: The Early Training Project. Baltimore: University Park Press.

Hernandez, D. J. (1997). Poverty Trends. In G. Duncan \& J. Brooks-Gunn (Eds.), Consequences of Growing Up Poor (pp. 18-34). New York: Russell Sage Foundation

Horacek, H. J., Ramey, C. T., Campbell, F. A., Hoffmann, K. P., \& Fletcher, R. H. (1987). Predicting school failure and assessing early intervention with high-risk children. American Academy of Child and Adolescent Psychiatry, 26, 758-763.

Huston, A. (Ed.). (1992). Children in poverty. New York: Cambridge University Press.

Infant Health and Development Program. (1990). Enhancing the outcomes of low-birth-weight, premature infants. Journal of the American Medical Association, 263, 3035-3042.

Lazar, I., Darlington, R., Murray, H., Royce, J., \& Snipper, A. (1982). Lasting effects of early education: A report from the Consortium for Longitudinal Studies. Monographs of the Society for Research in Child Development, 47(2-3, Serial No. 195).

Martin, S. L., Ramey, C. T., \& Ramey, S. L. (1990). The prevention of intellectual impairment in children of impoverished families: Findings of a randomized trial of educational day care. American Journal of Public Health, 80, 844-847.

McLloyd, V. C. (1998). Socioeconomic disadvantage and child development. American Psychologist, 53, 185-204.

NICHD Early Child Care Research Network (1997). Poverty and patterns of child care. In G. J. Duncan \& J. Brooks-Gunn (Eds.), Consequences of growing up poor (pp. 100-130). New York: Russell Sage Foundation.

Ramey, C. T. (1992). High-risk children and IQ: Altering intergenerational patterns. Intelligence, 16, 239-256.

Ramey, C. T., Bryant, D. M., Campbell, F. A., Sparling, J. J., \& Wasik, B. H. (1988). Early intervention for high-risk children: The Carolina Early Intervention Program. In H. R. Price, E. L. Cowen, R. P. Lorion, \& J. Ramos-McKay (Eds.), 14 ounces of prevention (pp. 32-43). Washington, DC: American Psychological Association.

Ramey, C. T., Bryant, D. M., Sparling, J. J., \& Wasik, B. H. (1985). Educational interventions to enhance intellectual development: Comprehensive day care versus family education. In S. Harel \& N. Anastasiow (Eds.), The "at-risk" infant: Psychological, social, and medical aspects (pp. 75-85). Baltimore: Brookes.

Ramey, C. T., Bryant, D. M., Wasik, B. H., Sparling, J. J., Fendt, K. H., \& LaVange, L. M. (1992). Infant Health and Development Program for low birth weight, premature infants: Program elements, family participation, and child intelligence. Pediatrics, $89,454-465$.

Ramey, C. T., \& Campbell, F. A. (1984). Preventive education for high-risk children: Cognitive consequences of the Carolina abecedarian project. American Journal of Mental Deficiency, $88,515-523$.

Ramey, C. T., Campbell, F. A., \& Blair, C. (1998). Enhancing the life-course for high-risk children: Results from the Abecedarian Project. In J. Crane (Ed.), Social programs that really work (pp. 163-183). New York: Sage.

Ramey, C. T., \& Finkelstein, N. W. (1981). Psychosocial mental retardation: A biological and social coalescence. In M. Begab, H. Garber, \& H. C. Haywood (Eds.), Psychological influences in retarded performance (pp. 65-92). Baltimore: University Park Press.

Ramey, C. T., \& Haskins, R. (1981). The causes and treatment of school failure: Insights from the Carolina Abecedarian Project. In M. Begab, H. Garber, \& H. C. Haywood (Eds.), Causes and 
prevention of retarded development in psychosocially disadvantaged children (pp. 89-112). Baltimore: University Park Press.

Ramey, C. T., MacPhee, D., \& Yeates, K. O. (1982). Preventing developmental retardation: A general systems model. In J. M. Joffee \& L. A. Bond (Eds.), Facilitating infant and early childhood development (pp. 343-401). Hanover, NH: University Press of New England.

Ramey, C. T., McGinness, G., Cross, L., Collier, A., \& Barrie-Blackley, S. (1981). The Abecedarian approach to social competence: Cognitive and linguistic intervention for disadvantaged preschoolers. In K. Borman (Ed.), The social life of children in a changing society (pp. 145-174). Hillsdale, NJ: Lawrence Erlbaum Associates, Inc.

Ramey, C. T., Mills, P. J., Campbell, F. A., \& O’Brien, C. (1975). Infants home environments: A comparison of high-risk families and families from the general population. American Journal of Mental Retardation, 80, 40-42.

Ramey, C. T., \& Ramey, S. L. (1998). Prevention of intellectual disabilities: Early interventions to improve cognitive development. Preventive Medicine, 27, 1-9.

Ramey, C. T., \& Ramey, S. L. (in press). The transition to school for "at-risk" children: A conceptual framework and related research. Commissioned paper for the Synthesis Conference on the Transition to Kindergarten, National Center for Early Development and Learning, Charlottesville, VA.

Ramey, C. T., Sparling, J. J., \& Wasik, B. (1981). Creating social environments to facilitate language development. In $\mathrm{R}$. Schiefelbusch \& D. Bricker (Eds.), Early language intervention (pp. 444-476). Baltimore: University Park Press.
Schweinhart, L. J., Barnes, H. V., Weikart, D. P., Barnett, W. S., \& Epstein, A. S. (1993). Significant benefits: The High Scope Perry Preschool project through age 27. Ypsilanti, MI: The High Scope Press.

Spiker, D., Ferguson, J., \& Brooks-Grunn, J. (1993). Enhancing maternal interactive behavior and child social competence in low birth weight, premature infants. Child Development, 64, 754-768.

Vygotsky, L. A. (1978). Mind in society: The development of higher psychological processes.: Cambridge, MA: Harvard University Press.

Wasik, B. H., Ramey, C. T., Bryant, D. M., \& Sparling, J. J. (1990). A longitudinal study of two early intervention strategies: Project CARE. Child Development, 61, 1682-1696.

Woodcock, R. W., \& Johnson, M. B. (1977). Woodcock-Johnson Psycho-Educational Battery: Part 2: Tests of academic achievement. Boston: Teaching Resources Corporation.

Zeskind, P. S., \& Ramey, C. T. (1978). Fetal malnutrition: An experimental study of its consequences on infant development in two caregiving environments. Child Development, 49, 1155-1162.

Zeskind, P. S., \& Ramey, C. T. (1981). Preventing intellectual and interactional sequelae of fetal malnutrition: A longitudinal, transactional, and synergistic approach to development. Child Development, 52, 213-218.

Received July 6, 1998

Final revision received November 23, 1998

Accepted November 25, 1998 
Copyright of Applied Developmental Science is the property of Lawrence Erlbaum Associates and its content may not be copied or emailed to multiple sites or posted to a listserv without the copyright holder's express written permission. However, users may print, download, or email articles for individual use. 